\title{
Analysis of the Development of Bali Cattle Population in Agriculture Ecosystem of Timor Island using System Dynamics
}

\author{
Asnath Maria Fuah ${ }^{1}$, Ahmad Yani ${ }^{1}$, Rudy Priyanto ${ }^{1}$, Bagus Priyo Purwanto ${ }^{1}$, Luki Abdullah ${ }^{1}$, Jefirstson Richset \\ Riwukore ${ }^{2}$, Fellyanus Habaora ${ }^{3} *$ \\ ${ }^{1}$ Departement of Animal Production, Bogor Agricultural University, Bogor, Indonesia \\ ${ }^{2}$ Departement of Management Science, University of Indo Global Mandiri, Palembang, Indonesia \\ ${ }^{3}$ Departement of Animal Production and Technology, Bogor Agricultural University, Bogor, Indonesia \\ *Coresponding author email: habaorafhomas@gmail.com
}

\begin{abstract}
Developing Bali cattle population in Timor Island, East Nusa Tenggara province carries a potential issue regarding cattle population. The objective of this research was to conduct an analysis and projection of the development of Bali cattle population in the agricultural ecosystem in Timor Island using system dynamics. The research was conducted from January to September 2018. The research location was determined purposively based on the characteristics of the agricultural ecosystem located in Kupang Regency and Kupang City. The research used 60 Bali cattle and involved 102 rancher respondents. Interviews and field observations were conducted to obtain primary and secondary data. Data analysis was done by building a system dynamics using Powersim and interpreting the simulation results for the next 30 years. The analysis results of the system dynamics showed that a declining population of Bali cattle over the next 19 or 25 years due to the ranchers' current behavior. The contributing factors included calf mortality that reached $29.6 \%$ per year; Bali cow mortality was up to $14.1 \%$ per year; calving interval was 22 months; traditional farm management that it is not economical; and the rate of livestock export reached $29.5 \%$ per year of the total population. Rancher management interventions and farm policies to reduce the inhibiting factors of cattle productivity are needed to maintain the population of Bali cattle in Timor Island, especially in the agricultural ecosystem.
\end{abstract}

Keywords: Bali Cattle population, agriculture ecosystem, system dynamics

Abstrak. Perkembangan populasi sapi Bali di Pulau Timor provinsi Nusa Tenggara Timur kemungkinan akan bermasalah dalam aspek populasi sapi. Tujuan penelitian ini adalah menganalisis dan meproyeksikan perkembangan populasi sapi Bali di ekosistem pertanian Pulau Timor menggunakan sistem dinamis. Penelitian dilaksanakan dari bulan Januari-September 2018. Lokasi penelitian ditentukan purposive berdasarkan karakteristik ekosistem pertanian yang berlokasi di Kabupaten Kupang dan Kota Kupang. Materi penelitian adalah sapi Bali sebanyak 60 ekor, dan melibatkan 102 responden. Data diperoleh melalui wawancara dan observasi lapang. Data yang digunakan adalah data primer dan sekunder. Analisis data dilakukan dengan cara membangun sistem dinamis menggunakan powersim dan menginterpretasi hasil simulasi untuk jangka waktu 30 tahun kedepan. Hasil analisis sistem dinamis menunjukkan adanya penurunan populasi sapi Bali kurun waktu ke 19-25 tahun mendatang secara signifikan apabila perilaku usaha peternakan dilakukan seperti saat ini. Faktor penurunan populasi sapi karena kematian pedet mencapai $29,6 \%$ per tahun; kematian induk sapi mencapai $14,1 \%$ per tahun; calving interval mencapai 22 bulan; manajemen peternakan tradisional sehingga tidak ekonomis; laju pengeluaran/penjualan ternak mencapai $29,5 \%$ per tahun dari total populasi. Intervensi manajemen maupun kebijakan peternakan untuk menurunkan faktor penghambat produktivitas sapi diperlukan untuk mempertahankan populasi sapi Bali di Pulau Timor, terutama di ekosistem pertanian.

Kata Kunci: populasi Sapi Bali, ekosistem pertanian, sistem dinamis

$\begin{array}{ll}\begin{array}{l}\text { Introduction } \\ \text { The natural increase of beef cattle }\end{array} & \begin{array}{c}\text { indicates the low productivity of beef cattle in } \\ \text { Indonesia from the view of population. } \\ \text { Sixty percent beef demand in Indonesia is }\end{array} \\ \begin{array}{c}\text { population in Indonesia is } 2.9 \% \text { per year on } \\ \text { average (Habaora et al., } 2019^{\mathrm{abc}} \text { ). National beef } \\ \text { production averages } 3.4 \% \text { per year so it needs }\end{array} & \begin{array}{l}\text { concentrated in the provinces of DKI Jakarta, } \\ \text { West java, and Banten (Riwukore and Habaora, }\end{array} \\ \begin{array}{ll}2019^{\mathrm{a}} \text { ). To fulfill beef demand, } 750 \text { cattle are } \\ \text { to import beef cattle from Australia (average } \\ 8.76 \% \text { per year) and beef meat (average } 9.74 \% \\ \text { per year) (Riwukore and Habaora, } 2019^{\mathrm{abc}} \text { ). It }\end{array} & \begin{array}{l}\text { slaughtered per day from the total cattle } \\ \text { supplied from Australian imports and brought in } \\ \text { from the provinces of East Java, Central Java, }\end{array}\end{array}$


Bali, West Tenggara, and East Nusa Tenggara (NTT). Bali cattle contribute an average of 26.9\% per year to beef cattle supply (Habaora, et al., 2019 ${ }^{c}$ ) and one of the biggest suppliers of Bali cattle is NTT province (Riwukore and Habaora, $2019^{\mathrm{b}}$ ). The total cattle supplied from NTT to beef consumer areas in Indonesia is between 55,000-63,000 heads per year according to NTT Governor Decree Number 207/Kep/HK/2012 about Quota Export of Beef Cattle (Priyanto, et al., 2020). The total cattle exported is lower than the quota before the 2000s, namely 60,000-80,000 heads per year (Habaora, 2015).

The decreased export quota of beef cattle, especially Bali cattle from NTT is allegedly due to the relatively low natural increase and productivity of Bali cattle. The contributing factors include (1) high calf mortality, averagely $37.5 \%$ per year (Mahbubi, 2015; Habaora, et al., $2019^{c}$ ); (2) a very high mortality of productive female, $\geq 20 \%$ per year (Lole et al., 2013; Riwukore and Habaora, 2019a); (3) a high slaughter rate of productive female in Slaughterhouse, $>60 \%$ of the total slaughter per day (Mahbubi, 2015; Habaora, et al., 2019ª); (4) limited quality and quantity of feed feed due to long dry season (>8 month) rendering cattle malnourished (Kleden, Ratu, and Randu, 2015; Priyanto et al., 2015; Riwukore and Habaora, $\left.2019^{c}\right)$; (5) traditional cattle raising system with low production inputs (Mahbubi, 2015; Riwukore and Habaora, 2019 $)$; (6) the high prevalence of brucellosis and anthrax endemic in an area that causes livestock mortality to reach $27.7 \%$ per year (Habaora, 2015; Habaora et al., 2019); (7) the government's limited role in improving the ability of ranchers in farm management (Riwukore and Habaora, 2019 ) and weak supervision of cattle exports so the realization of exports is higher than the determined quota (Riwukore and Habaora, 2018; Habaora et al., 2019 ${ }^{\mathrm{C}}$ ); and (8) decreased bodyweight of Bali cattle exported from 450 $\mathrm{kg} / \mathrm{head}$ in $1970-1980$ to $275 \mathrm{~kg} / \mathrm{head}$ in 2015 -
2019 (Kleden et al., 2015; Fuah et al., 2015; Priyanto, 2016; Riwukore and Habaora 2018).

The center of Bali cattle production in NTT is Timor Island where $66.9 \%$ of cattle population $(593,408)$ across NTT $(899,577)$ are spread (BPS, 2018). The role of Timor Island as a production area in fulfilling the national demand of beef (Indonesia) could pose an issue regarding population because exporting Bali cattle out of Timor Island because the area is considered not fully capable of providing the supply and the production system of Bali cattle which remains poor. Habaora et al. $\left(2019^{\mathrm{a}}\right)$ reported that Bali cattle in Timor Island have low reproductive performance because (1) age of female cattle when mated male/insemination when it has reached the age of 1.7 years so that it affects the age of the first partus into long ( $>2.8$ year); (2) long estrous cycle; (3) female cattle fertility is low, causing the value of service per conception to be high although having a calf crop value that is good enough for dry tropics; (4) long days open value; (5) low female conception rate; (6) long calving intervals. This situation has caused the low rate of increase in the population of Bali cattle in Timor Island, around $<11.2 \%$ per year.

In general, Timor Island is a type of dry land with low cattle productivity. Feed limitations are a major inhibiting factor for cattle productivity, although it has the potential for agricultural ecosystems as a source of feed from an agricultural waste of irrigation and nonirrigation an area of 317,279 hectare (BPS, 2018; Riwukore and Habaora, 2018). The existence of factors inhibiting the productivity of Bali cattle in Timor Island if not studied scientifically would speed up the decrease of Bali cattle population because it is not considered as the ability of the region. Therefore, it is essential to conduct a study using a system dynamics approach in agricultural ecosystems to project a model of Bali cattle population in Timor Island provided 
that the ranchers and farm stakeholders continues their current farming behaviour.

The population of Bali cattle is significantly influenced by the population structure, starting from the calving, growing until mature, and culling, as well as the growth phase and development that include mortality, calf crop, and sales. In 1950 Jay W Forrester introduced one analytical tool that connected various kinds of variables that influence each other (causal loop) called a system dynamics analysis tool, namely information sources and information flow networks that are interconnected to form structures information system (Muhammadi et al., 2001). Yani (2013) explains that systems dynamics are methods that can describe the process of behavior and complexity arising from the cause and effect of various variables in the system. Therefore, this research used a system dynamics analysis to project the growth and development of Bali cattle population for 30 years using a system dynamics modeling of Bali cattle population.

\section{Materials and Methods}

The research was conducted in Timor Island of NTT on an agriculture ecosystem for 1 year, from January to December 2018. The location of the research was selected purposively based on the some criteria, such as physical (land area), biological (availability and population of Bali cattle), and socio-cultural (the condition of ranchers in the target location and policies that support the Bali cattle program in Timor Island). The areas that best represent this condition are situated in Kupang District and Kupang City. The research used 60 Bali cattle selected using a random sampling cluster and involved respondents accounted for $5-10 \%$ of the total Bali cattle ranchers (102 respondents) residing in the areas and breeding $>10$ heads of Bali cattle. The respondents were interviewed using a questionnaire (open-ended questions). In addition to interviews, field observations were also carried out. This research used and processed the primary data using Powersim 2.5 program for Windows. The model is developed through a system approach method. The phase of making analysis and simulation models are (1) conceptualization of the system and problem solving; (2) identification of system and problem settlement; (3) flow chart model (model structure); and (4) use of the model (Yani, 2013; Wynn and Clarkson, 2018) for the next 30 years. The reason for selecting the time range is due to the general long-term regional plans that last for 30 years.

\section{Results and Discussion}

\section{Conceptualization of the System and Problem Solving}

The problems of developing Bali cattle population in agricultural ecosystems involves many elements, namely the calves ratio of male and female cattle, cattle mortality at each age structure, production age, female reproductive status (conception, weaned calf, calving interval, conception rate) and the total cattle sold as beef cattle. These issues are considerably complex and would continue to change and develop over time, so it should be addressed properly using the system dynamics approach with powersim (Yani, 2013; Galioto et al., 2017).

\section{Identification of System and Problem Settlement}

System identification is the process of design to produce a picture of the relationship between elements (entities) and the relationship of input and output from the operation of a system. The relationship between the factors that influence elements of the Bali cattle population in the ecosystem of Timor Island can be seen in Figure 1. 


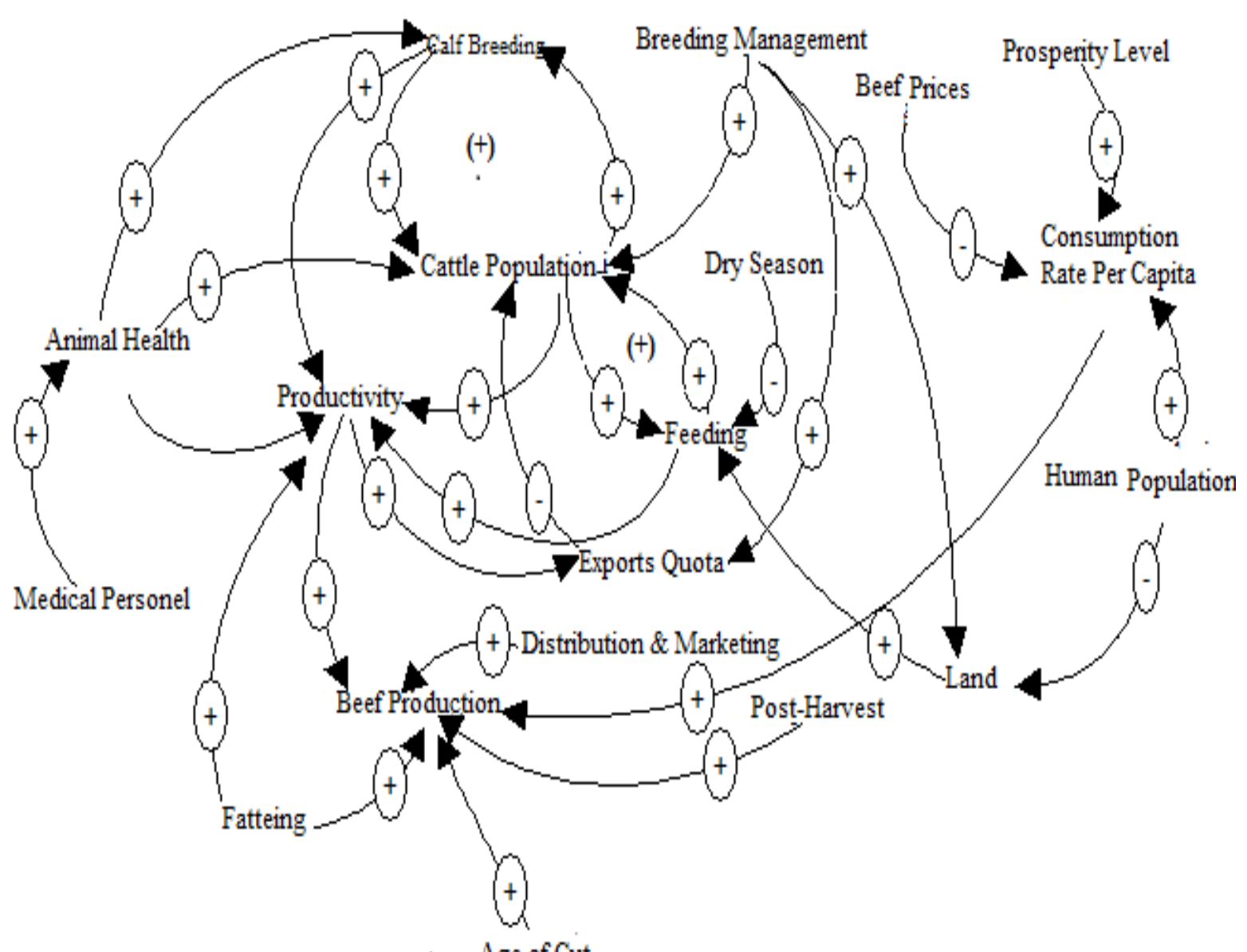

Age of Cut

Figure 1. Model of Bali cattle population

Figure 1 illustrates that the main focuses of the model of Bali cattle population in the agriculture ecosystem of Timor Island are Bali cattle population and its productivity which have a causal loop with various factors. The development of female cattle population is influenced by the rate of female calf crop that will grow and develop into adult cows and culling female. Changes in physiological and body function of heifers and adult females cause increasing the reproductive capacity (conception) of female cattle to add the cattle population, but the reproductive status of female cattle is influenced by reproductive performance such as conception rate, calving interval, and age of production. The existence of mortality factor in each structure of female cattle population is very significant to the decrease in Bali cattle population. BPS (2018) reported that in 2000 , the cattle population in
NTT reached 1.2 million heads compared to 2018 which had decreased to 800,000 cattle.

The development of the male cattle population is influenced by the structure from male calves that will birth, growing and developing until it becomes cattle of culling. The availability of males as the main beef cattle producer is influenced by the rate of birth, death, and age of production. Calf crop of male is influenced by the population of partus females, and the calf crop of male influences the rate of natural increase in the population of Bali cattle on agriculture ecosystem of Timor Island. These data and information are then simulated into a model so that the results of the Bali cattle population are the same between the real world and the expected behavior. The perception conclusion of this population model is very logical. The purpose of designing a model in this research is to identify the 
development in the population of Bali cattle in the agriculture ecosystem of Timor Island using system dynamics. In general, the model can be used and useful for resource management that focuses on the population of Bali cattle. Riwukore et al., (2020) stated that the growth of the cattle population is very dependent on the reproductive ability of female and male livestock to produce offspring, in addition to interventions of technology and management.

\section{Models Structure}

Model structure will give shape to the system and at the same time characteristics that influence the behavior of the system. The behavior is formed by a combination of causal loops that make up the structure of the model. All model behavior, however complex, can be simplified into a basic structure, namely the mechanism of input, process, output, and feedback. The mechanism will work according to changes in time or be dynamics which can be observed behavior in the form of performance (level) of a dynamics model. The making of a model flow chart (structure model) is based on system dynamics equation that includes the state level (population), flow (age of structure population), auxiliary (elemental dynamics), and constant (fraction of influence) and is described by symbols and relationships (Figure 2).

The relationship marked with an arrow in Figure 1 is then converted to a numerical equation with clear units in the time variable. This stage is carried out quantification of the model by referring to making causal loops so that it can be simulated with software systems dynamics as shown in Figure 3 and Figure 4.

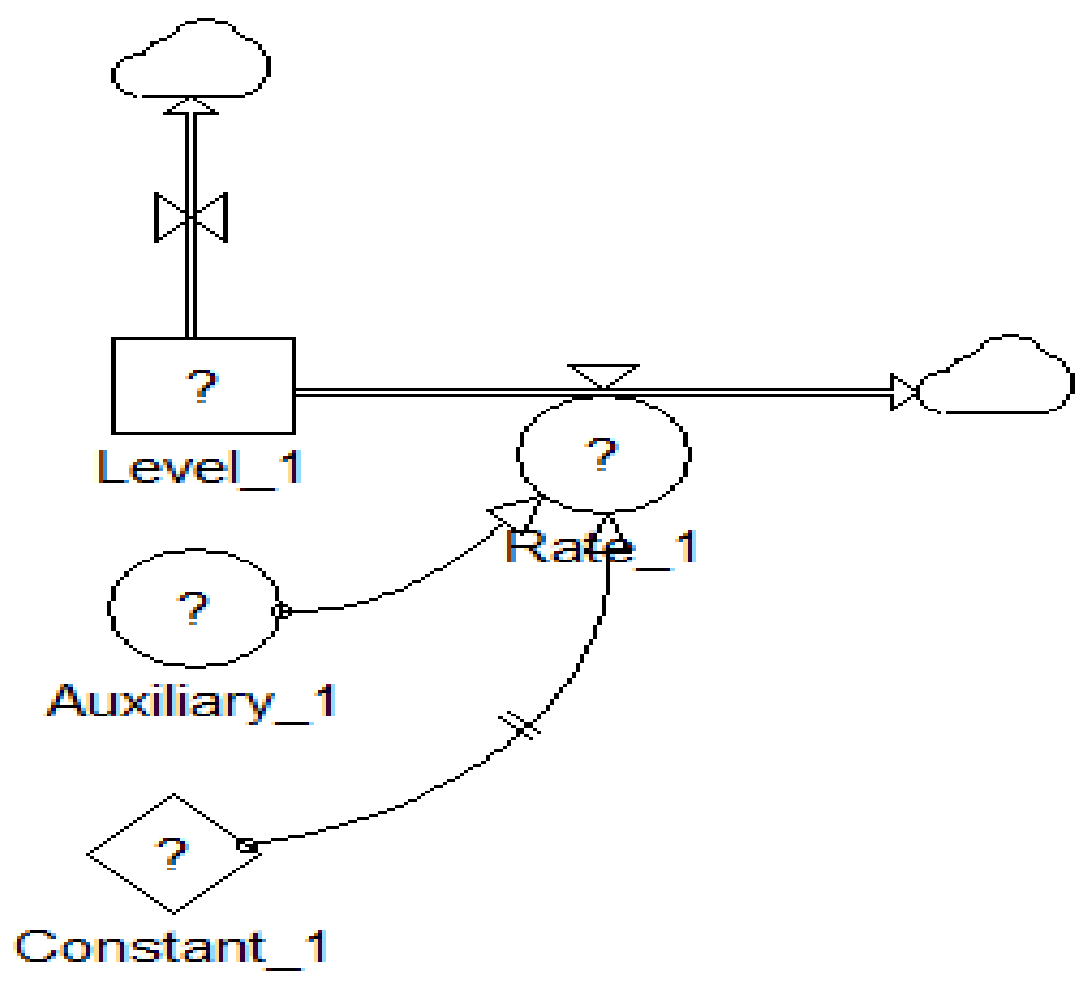

Figure 2. Symbols and relationships in system dinamics 
Asnath Maria Fuah et al./Animal Production. 22(2):105-117, 2020

Accredited by Kemenristek Dikti No 32a/E/KPT/2017. ISSN 1411-2027

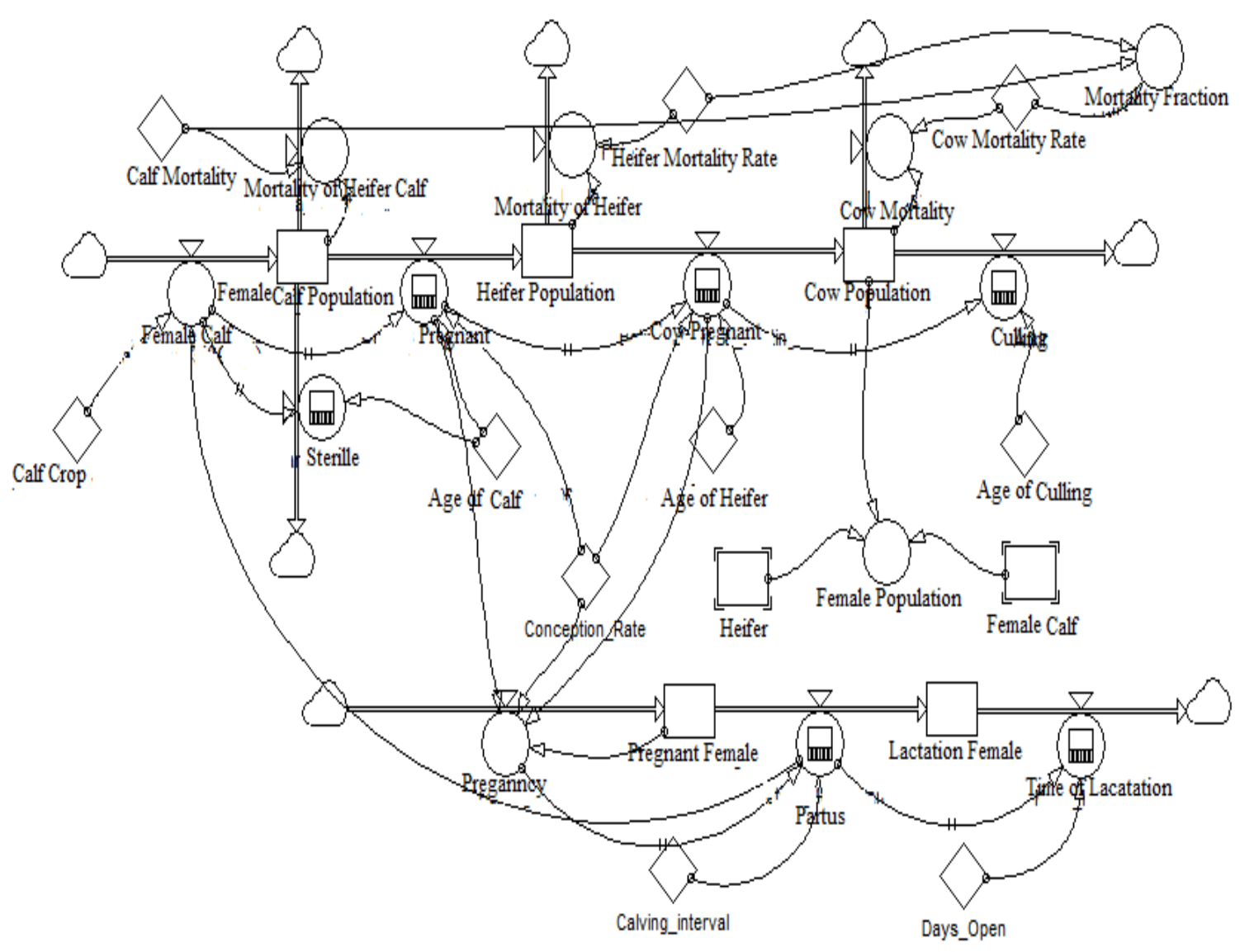

Figure 3. Model of female Bali cattle population

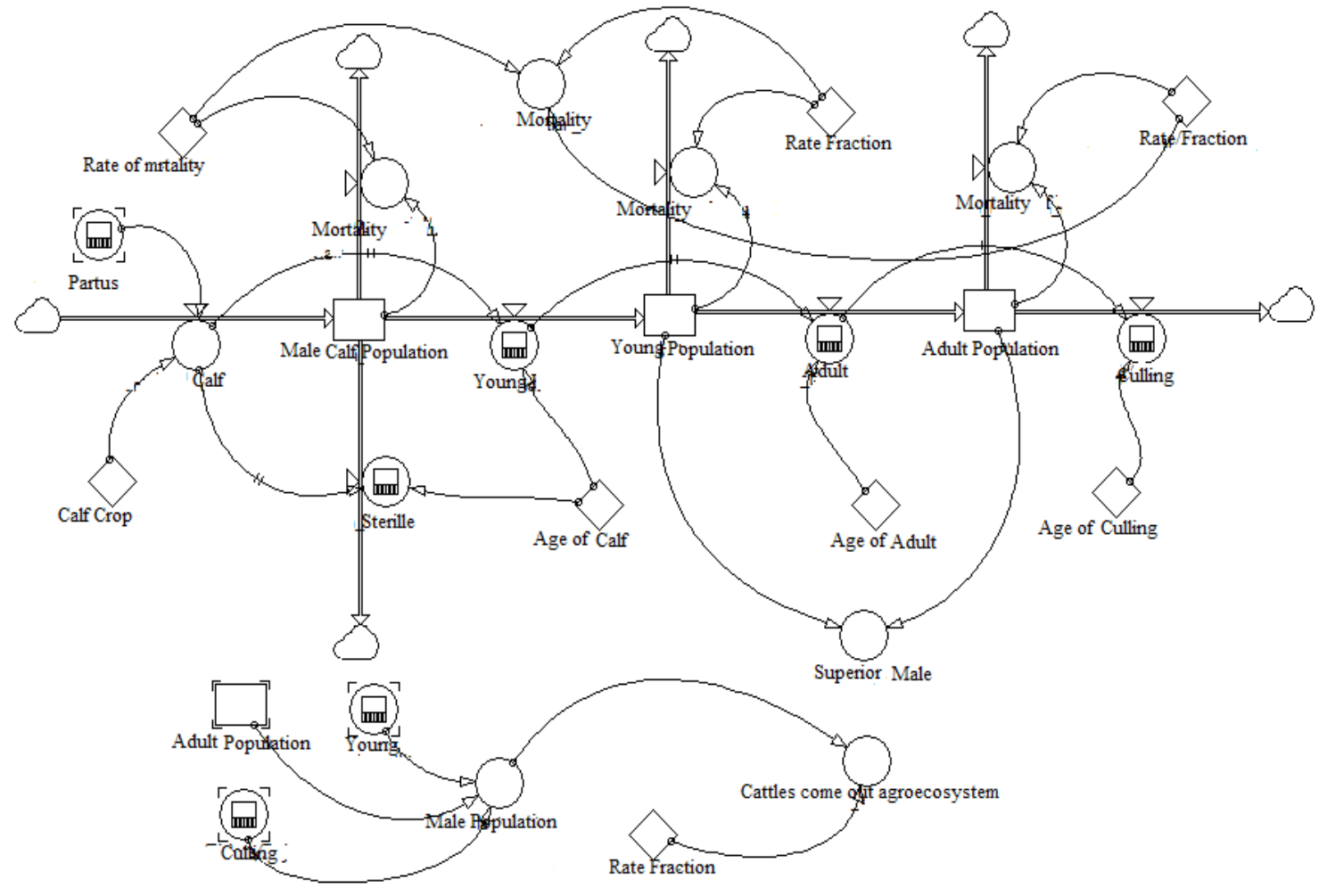

Figure 4. Model of male Bali cattle population 
Table 1. Existing condition from Bali cattle population in 2018

\begin{tabular}{|c|c|c|c|}
\hline \multirow{2}{*}{ No. } & \multirow{2}{*}{ Data of Population Model } & \multicolumn{2}{|c|}{ Sex Ratio } \\
\hline & & Female & Male \\
\hline \multirow[t]{6}{*}{1.} & Bali cattle population (head cattle) & & \\
\hline & - Calf & 113 & 183 \\
\hline & - Young & 272 & 273 \\
\hline & - Adult & 368 & 434 \\
\hline & - Culling & 29 & 77 \\
\hline & Total & 782 & 967 \\
\hline \multirow[t]{4}{*}{2.} & Status of female reproduction & & \\
\hline & - Pregnancy & 17 & - \\
\hline & - Partum cow & 33 & - \\
\hline & - Lactation cow & 44 & - \\
\hline \multirow[t]{12}{*}{3.} & Fraction of influence factor (\%) & & \\
\hline & Calf ratio & 49.2 & 50.8 \\
\hline & Mortality & & \\
\hline & - Calf & 27.3 & 32.5 \\
\hline & - Young & 9.6 & 12.4 \\
\hline & - Adult & 4.5 & 8.5 \\
\hline & Conception rate & 53.4 & - \\
\hline & Cattle of left from ecosystem & & \\
\hline & - Female culling & 17.4 & - \\
\hline & - Male culling & - & 35.8 \\
\hline & - Steer & - & 27.2 \\
\hline & - Adult male & - & 41.4 \\
\hline \multirow[t]{7}{*}{4.} & Fraction of production age (month) & & \\
\hline & - Calf age & 6 & 6 \\
\hline & - Young age & 19 & 20 \\
\hline & - Adult age & 60 & 58 \\
\hline & - Age of culling & 88 & 95 \\
\hline & - Days open & 9 & - \\
\hline & - Time of conception & 9,4 & - \\
\hline
\end{tabular}

The Bali cattle population model in the agriculture ecosystem of Timor Island is significantly influenced by the birth and death of livestock, age distribution, cattle left the ecosystem, and the reproductive status of female Bali cattle. An improved reproductive status of female Bali cattle influences the natural increase value. Information and data used in the dynamic systems model for the current conditions of Bali cattle populations are presented in Table 1.

\section{Use of the Model}

This simulation applies if Bali cattle population (female and male) in the ecosystems is managed according to data and information that have been made available or previously processed (business as usual). The results of the simulations that were carried out on the existing conditions periodically (30 years) are presented in Figure 5 and Figure 6.

The dynamic systems simulation results in Figure 5 show a significant decrease in female Bali cattle population over the next 25 years, then a slow increase starts on the 26th year. The decrease in female calf population affects the decrease in female Bali cattle population (young and adult) followed by the population of female cattle for culling. The rate of decrease in the population of calf cattle as a generation (replacement stock) affects the total decrease of female Bali cattle in the ecosystem of Timor Island. This research produced information that if ranchers and farm stakeholders (government 
and private) continue the current behaviour in livestock business, the farm activities are considered ineffective and inefficient.

Factors affecting the decrease in female Bali cattle population in agricultural ecosystems are (1) calf mortality is quite high (27.3\% per year); (2) mortality is relatively high for female cattle of young and adult (14.1\% per year); (3) heifers have a long calving interval value based on the conception age and days open (22 months) despite the high conception rate (53.4\%); and (4) ranchers still maintain livestock that is no productive (culled cattle). Vasconcelos et al. (2017) states that the low value of natural increase can affect the need for female calves as a prospective substitute for replacement stock and the addition of the livestock supply owned by an area. Crowe et al. (2018) stated that the scale of the natural increase value is very influenced by factors of livestock mortality in the population. The higher mortality rate from livestock affects the acceleration of the decrease in natural increase value, and if the mortality rate is lower, the natural increase value will increase. Gusha et al. (2013) and Habaora et al. $\left(2019^{c}\right)$ stated that a long calving interval in Bali cattle farm in Timor Island is generally because the calves are not weaned so the first estrous after postpartum is extended, the conception of female cattle takes a long time, the failed conception and service per conception are high, and the age on the first female conception is slow. Bures and Barton (2012) stated that the slaughter of female cattle was carried out if the livestock had a low reproductive performance.

Scenarios of improving the current condition of female Bali cattle in the agriculture ecosystem of Timor Island can be done by reducing the mortality rate of the female cattle and reducing the calving interval value.
Ranchers are also expected to not delaying the cull of unproductive female cattle for too long so to save farmers from maintenance burden. Yani (2013) reported several steps that can be taken by ranchers and local governments in improving the performance of female livestock reproduction to improve the natural increase value in population, namely (1) improving the genetic quality of livestock in order to produce steer cattle, the breed of superior livestock; (2) applying artificial insemination techniques to increase the percentage of mating livestock; (3) providing an extension to the ranchers and livestock industry about the techniques of cultivating beef cattle; (4) provide livestock infrastructures (facilities and infrastructure), such as the feed industry, livestock farming equipment, and medicines. Fouz et al. (2011) and Priyanto et al. (2015) explained that improving the quality and quantity of productivity of Bali cattle can be done by reducing calving intervals, saving productive females, delaying cattle slaughtering time, and applying artificial insemination (Al) / controlled mating to increase the value of conception rate.

The simulation results in Figure 6 show that the periodic time is from the present until the $19^{\text {th }}$ time period to the next, an existence of a decrease in the population of male calves followed by a decrease in the population of young cattle (steer) up to a time period of 23 years, then followed by a decrease in the adult male cattle population until the $30^{\text {th }}$ time period to come. Thereafter, there would be a slow increase in the population of male Bali cattle in each age structure for the next 30 years. Over the next 30 years, the cattle population development of culling shows a flat graph because male cattle that reach the age of culling generally have left the ecosystems or sold as beef cattle. 


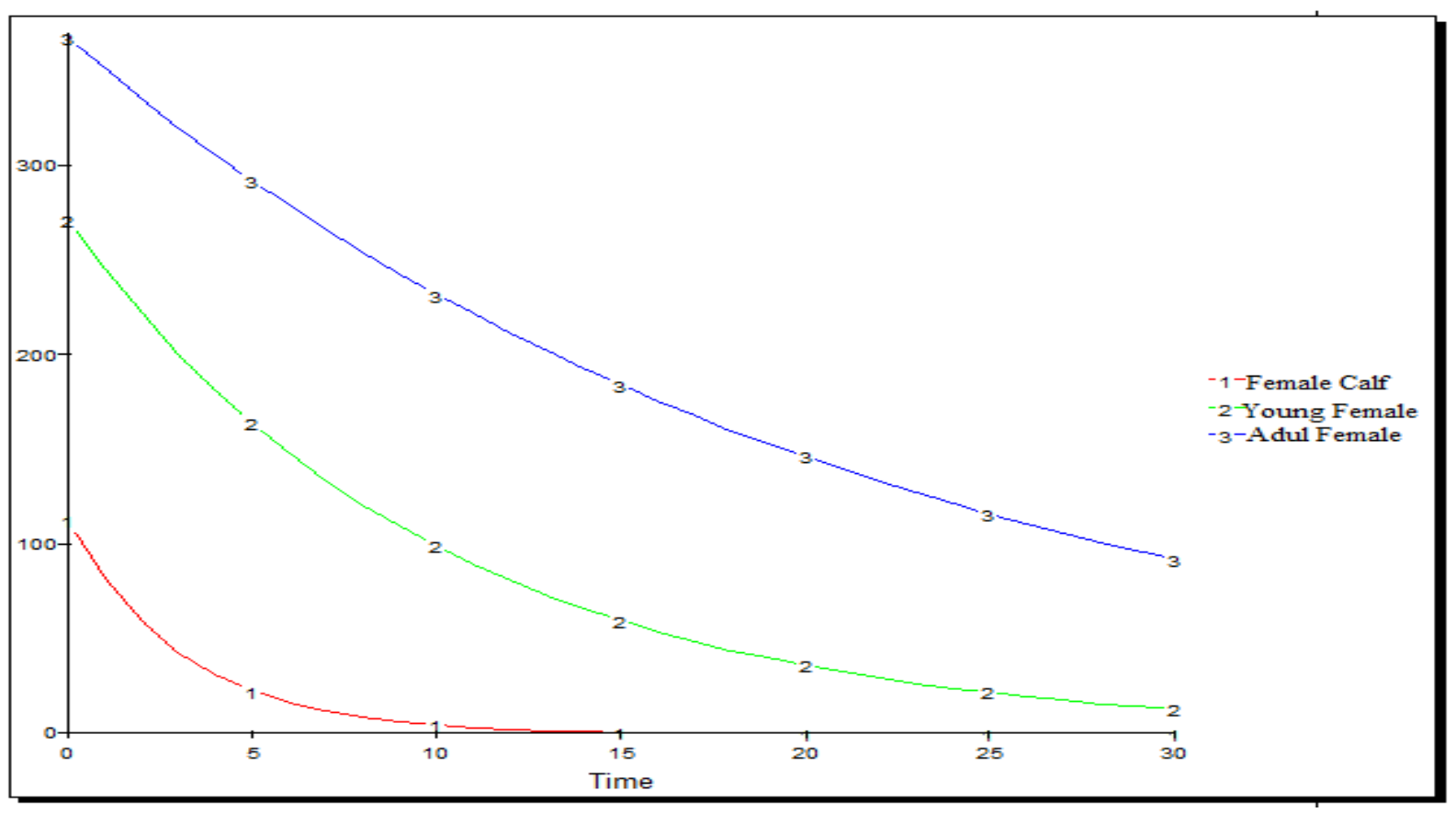

Figure 5. Simulation diagram of female Bali cattle population for 30 years

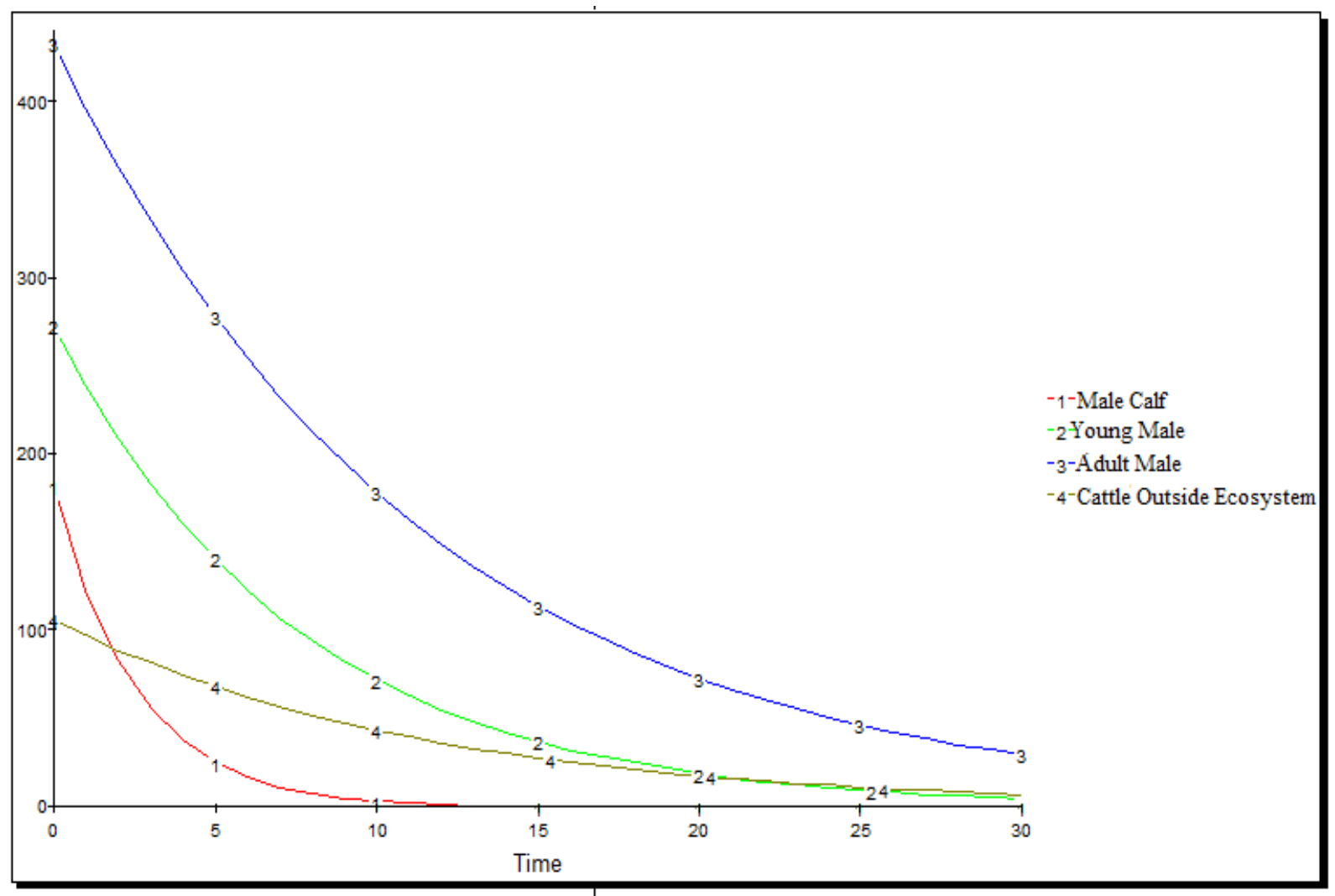

Figure 6. Simulation diagram of male Bali cattle population for 30 years

The development of the male cattle sold/excreted from ecosystems to be used as population (adult and culling) seems slow steer cattle. Male calves that are born will add because most of the young cattle have been to the structure of the population of young 
cattle that grow and develop into adult cattle, then become cattle of culling. The death of Bali cattle at every age structure affects the decrease in Bali cattle population. The slowdown in the development of a male population of adult and culling is due to the fact that most of the cattle are sold from the ecosystem as beef cattle, whether delivered or put into slaughterhouses to be slaughtered as domestic beef production.

Based on the results of the system dynamics simulation on the model of male Bali cattle population in the ecosystem of Timor Island Agriculture (Table 1), the contributing factors to the low development of male Bali cattle population are (1) a considerably high rate of male calf mortality, by $32.5 \%$ per year; (2) a considerably high rate of young and adult mortality, by $12.4 \%$ and $8.5 \%$, respectively; (3) a very high rate of cattle exports from ecosystems, averagely $29.5 \%$ per year. Restoring Bali cattle production system in the ecosystem would determine the natural increase value of Bali cattle.

Some researchers reported that natural increase value in the population of Bali cattle in Timor Island in NTT was still low due to factors, including (1) the high calf mortality (35-40\%) followed by high mortality rate of productive female ( $>20 \%$ ) of the total population of Bali cattle (Lole et al., 2013; Mahbubi, 2015; Habaora, 2015; Riwukore and Habaora, 2018; Riwukore and Habaora, 2019 ; Habaora, et al., $2019^{\mathrm{abc}}$ ); (2) the rise of traditional farming of Bali cattle in Timor Island that decreased the production inputs of Bali cattle (Fuah et al., 2015; Priyanto et al., 2015; Habaora et al., 2019'; Riwukore and Habaora, 2019'); and (3) livestock expenditure rate (export of cattle from NTT to beef consumer areas) that have not considered the carrying capacity and capability of ecosystems in Timor Island (Mahbubi, 2015; Priyanto, 2016). Limited feed availability, accompanied by the characteristics of ranchers, livestock management, and weak local government policies in improving the production system of Bali cattle in Timor Island further accelerate the decrease of Bali cattle in Timor Island (Ratnawaty and Budianto, 2011; Susilawati, 2011; Lole et al., 2013; Mahbubi, 2015; Habaora et al., 2019 ${ }^{\mathrm{b}}$ ).

The growth and development of Bali cattle population is related to the ratio of the population (female and male), calf crop, mortality rate, the status of female reproductive, and magnitude of cattle expenditure from ecosystems (sold) as beef cattle from an ecosystem (area). If an area or ecosystem have a high natural increase value, the number of productive females and the handling management are optimum. If the mortality rate is high, it will decrease the natural increase value and further decrease the cattle population because the female of reproduction status is low (Novakovic et al., 2011; Martins et al., 2012; Vasconcelos et al., 2017; Habaora et al., $2019^{c}$ ). The expenditure of cattle from an ecosystem that ignores the carrying capacity and production capacity will speed up the declining population (Khan et al., 2012; Lardner et al., 2014).

\section{Recommendation of Policies}

Analysis of Bali cattle population development in an agriculture ecosystem in Timor Island using system dynamics of production information and data show that if ranchers and farm stakeholders continues their current behaviour in livestock business, Bali cattle population (male and female) is projected to decline significantly in the next 19-25 year because of high calf mortality and low reproductive ability of females, and start to increase slowly in the $26^{\text {th }}$ year. It is evident that the current farm business is ineffective and inefficient. Improving the current conditions of Bali cattle farms in the agriculture ecosystem of Timor Island may include several measures that include the intervention to improve the management of Bali cattle farms in agricultural 
ecosystems through calf crop inventory; the increase of natural population every year to support the replacement stock of Bali cattle; improvement of reproductive status of female Bali cattle based on the age structure of the population and reproductive efficiency; and limitation on the expenditure/sale of cattle from Timor Island ecosystem according to the output value.

Some researchers reported that restoring the productivity of beef cattle based on the cattle population can be done through reducing the mortality rate of Bali cattle and increasing the value of calf crop cattle, as well as increasing the use of superior males or artificial insemination and limiting livestock expenditure from ecosystems (Priyanto et al., 2015; Fuahet al., 2015; Priyanto, 2016; Dinata et al., 2019; Habaora et al., 2019 $)$. Yani (2013) stated that several steps that can be taken by ranchers and local governments in improving the performance of female livestock reproduction to improve the natural increase value in population, namely (1) improving the genetic quality of livestock in order to produce steer cattle, the breed of superior livestock; (2) applying artificial insemination techniques to increase the percentage of mating livestock; (3) providing an extension to the ranchers and livestock industry about the techniques of cultivating beef cattle; (4) provide livestock infrastructures (facilities and infrastructure), such as the feed industry, livestock farming equipment, and medicines.

Based on the description above, the researchers proposed some policy recommendations to different stakeholders. First, ranchers and the local government can increase Bali cattle population in agricultural ecosystems by limiting livestock mortality up to $2 \%$, increasing the calf crop value up to $80 \%$, reducing the calving interval value to 1 year. Additionally, they should prioritize the improvement of reproductive and productive performance within the next 26 years by increasing the role of extension workers and inseminators, improving health management, and improving animal feed conditions. It is also important to limit cattle expenditure from ecosystems namely a maximum of $10 \%$ of the population.

Secondly, the government and stakeholders should launch a campaign and enforcement of Law No. 18 of 2009 (revised to Law No.41 of 2014 on Animal Husbandry and Health) especially related to the stability and sustainability of livestock populations in one area. This phase is followed by periodic monitoring to ensure that violations do not occur.

At last, the government and stakeholders need to review the strategy for overcoming and eradicating endemic diseases based on regions. In addition, the limited availability of productive females in the ecosystem is also accompanied by the fertility of females which is still low so it is necessary to carry out a strict supervision of the actions of slaughtering productive females so as not to increase the significance of decrease in natural increase value. The local government also needs to work to improve the status of livestock reproduction so as to accelerate and improve the quality of Bali cattle breeds in the agriculture ecosystem of Timor Island.

\section{Conclusions}

The analysis of the development of Bali cattle population in Timor Island agricultural ecosystem based on the simulation of current data and projections for the next 30 years concludes that the population of Bali cattle in the agricultural ecosystem has decreased significantly. The contributing factors are the high mortality of Bali cattle (male and female) in each age structure (calf, young, and adult), low status of Bali cow reproduction, low reproductive efficiency, poor management of livestock productive age, and an imbalance between the total cattle expenditure/sales and 
the ecosystem ability. The decrease of the inhibiting factors of Bali cattle productivity is the best way to increase the population of cattle in the agricultural ecosystem in Timor Island.

\section{References}

BPS. 2018. Provinsi Nusa Tenggara Timur dalam angka. Kupang: Badan Pusat Statistik Nusa Tenggara Timur.

Bures and L. Barton. 2012. Growth performance, carcas traits and meat quality of bulls and heifers slaughtered at different ages. Czech J.Anim.Sci, 57, 34-43.

Crowe, M. A., M. Hostens and G. Opsomer. 2018. Reproductive management in dairy cows the future. Irish Veterinary Journal, 71, 1-13.

Dinata, A. A., Y. Pujiawati and S. Aurum. 2019. Productivity of Bali cattle feed ration supplemented by mollasses containing several types of defaunation agents. Jurnal IImu Ternak dan Veteriner, 24.(2), 49-54.

Fouz, R., F. Gandoy, M.L. Sanjuan, E. Yus and F.J. Dieguez. 2011. Factors associated with 56-day non return rate in dairy cattle. J.Pesq.Agropec.Bras. , 46(6), 648-654.

Fuah, A. M., J. Petheram and R. Priyanto. 2015. Evaluation of farming system research (FSR) on small livestock in Timor Barat Nusa Tenggara Timur. Jurnal Ilmu Produksi dan Teknologi Hasil Peternakan, 3(1), 12-20.

Galioto, F., C. Paffarini, M. Chiorri, B. Torquati and L. Cecchini. 2017. Economic, environmental, and animal welfare performance on livestock farms: Conceptual model and application to some case studies in Italy. Sustainability Journal, 9, 1-22.

Gusha, J., S. Katsande, P.I. Zvinorova and I. Tavengwa. 2013. Calving period affects cow and calf performance in semi-arid areas in Zimbabwe. IOSR Journal of Agruculture and Veterinary Science, 3, 61-65.

Habaora, F. 2015. Pasture of tropical land (Padang penggembalaan daerah tropis). Yogyakarta, Indonesia: Deepublish Press.

Habaora, F., A.M. Fuah, L. Abdullah, R. Priyanto, A. Yani and B.P. Purwanto. 2019. Attitude analysis of Bali cattle farmers toward credit program based on agroecosystems in Timor Island. International Journal of Innovative Science and Research Technology, 4(9), 769-776.

Habaora, F., A. M. Fuah, L. Abdullah, R. Priyanto, A. Yani and B.P. Purwanto. 2019. Economic analysis of Bali cattle Farm in Timor Island Indonesia. International Journal of Scientific and Technology Research, 8(10), 1576-1582.
Habaora, F., A. M. Fuah, L. Abdullah, R. Priyanto, A. Yani and B.P. Purwanto. 2019. Reproduction performance of Bali cattle on agroecosystem in Timor Island. Ternak Tropika: Journal of Tropical Animal Production, 20(2), 141-156.

Khan, S., M.S. Qureshi, N. Chand, A. Sultan, Rafiullah, I. Khan. 2012. Effect of breeding method on calf sex and postpartum reproductive performance of cattle and buffaloes. Sarshad J.Agric., 28(3), 469476.

Kleden, M. M., M. R. Ratu and M.D. Randu. 2015. Carrying capacity of forage in coffee farm and native pasture area at district of Flores Timur Nusa Tenggara Timur. Jurnal Zootek, 35(2), 340350.

Lardner, H. A., D. Damiran, S. Hendrick, K. Larson, and R. Funston. 2014. Effect of development system on growth and reproductive performance of beef heifers. J.Anim.Sci. , 92, 3116-3126.

Lole, U. R., S. Hartoyo, Kuntjoro and I.W. Rusastra. 2013. Analysis of regional distribution capacity and priorities for improving beef cattle population in East Nusa Tenggara province. Jurnal Media Peternakan. , 36(1), 70-78.

Mahbubi, A. 2015. Madura development program as cattle island sustainable supply chain management perspective. Agriekonomika: Jurnal Sosial Ekonomi dan Kebijakan Pertanian, 3(2), 94105.

Martins, P. G., J.D. Arthington, R.F. Cooke, C.G. Lamb, D.B. Araujo, C.A. Torres. 2012. Evaluation of beef cattle and calf separation system to improve reproductive performance of first calf cows. J.Livestock.Science, 150, 74-79.

Muhammadi, E., Aminullah and B. Soesilo. 2001. Analysis of dinamic system: environmental, social, economy, management. Jakarta, Indonesia: UMJ Press.

Novakovic, Z., L. Sretenovic, A. Aleksic, M.M. Petrovic, V. Pantelic, and D. Ostojic-Andric. 2011. Age at first conception of hight yielding cows. Journal Biotechnology in Animal Husbandry, 27(3), 1043-1050.

Priyanto, D. 2016. Strategies to return Nusa Tenggara Timur as a source of beef cattle. Jurnal Penelitian dan Pengembangan Pertanian, 35(4), 167-178.

Priyanto, R., A. M. Fuah, E. L. Aditia, M. Baihaqi and M. Ismail. 2015. Improving productivity and meat quality of local beef cattle throught fattening in cereals based feed with different energy levels. Jurnal IImu Pertanian Indonesia, 20(2), 108-114.

Priyanto, R., J.R. Riwukore, A. Yani, B.P. Purwanto, L. Abdullah, A.M. Fuah. 2020. Analysis of dinamic system toward Governor policy of Nusa Tenggara Timur about quota of beef cattle export (Case study in plantation agroecosystem of Timor 
Island). Annual Research and Review in Biology, 35(5), 32-41.

Ratnawaty, S. and D.A. Budianto. 2011. Business opportunities for fattening cattle in group pens in Tobu Village, South Central Timor District, East Nusa Tenggara. Jurnal Ternak Tropika, 12(2), 5259.

Riwukore, J. R. and F. Habaora. 2018. Sistem produksi sapi potong. Jogjakarta: Deepublish.

Riwukore, J. R. and F. Habaora. 2019. Beef cattle productivity development strategy at Pasture Konetuef. International Journal of Current Research, 11(6), 4244-4247.

Riwukore, J. R. and F. Habaora. 2019. Perception of farmers on the performance of extensionist in the pasture agroecosystem of Timor Tengah Utara District. Asian Journal of Agricultural Extension, Economics and Sociology, 29(2), 1-10.

Riwukore, J. R. and F. Habaora. 2019. Profile of existing population density and supporting capacity of beef cattle in Indonesia. International Journal of Recent Academic Research, 1(2), 6471.

Susilawati, T. 2011. Tingkat keberhasilan inseminasi buatan dengan kualitas dan deposisi semen yang berbeda pada sapi Peranakan Ongole. Jurnal Ternak Tropika, 12(2), 15-24.

Vasconcelos, J.L., R. Carvalho, R.F. Peres, A.D. Rodrigues, I.J. Junior, M. Meneghetti. 2017. Reproductive programs for beef cattle: Incorporating management and reproductive techniques for better fertility. J.Anim.Reprod., 14(3), 547-557.

Wynn, D. C. and P.J. Clarkson. 2018. Process models in design and development. J.Res.Eng.Desighn, 29, 161-202.

Yani, A. 2013. Need analysis of cow and poultry slaughtering house in West Java by using dinamic system. Jurnal Ilmu Produksi dan Teknologi Hasil Peternakan, 1(2), 15-26. 